\title{
The Social Life of Reconciliation: Religion and the Struggle for Social Justice in Post-New Order Indonesia $^{1}$
}

\author{
Fadjar I Thufail \\ Research Center for Regional Resources \\ Indonesian Institute of Sciences
}

\section{Introduction}

Anthropologists of law have long studied reconciliation to understand how people resolve disputes. Studies on conflict resolution and on reconciliation examine a general process of reconciliation deployed to restore harmony and prevent retaliation. This role of reconciliation often becomes a significant part of the Alternative Dispute Resolution (ADR) procedure that seeks to include local actors and local institutions in dispute resolutions. Studies of ADR often assume that reconciliation takes place between individuals or groups of individual over issues related to, among others, property, domestic violence or inheritance.

My research wants to bring the state back into the analysis of reconciliation by introducing the state, or those representing the interests of the state, as a party to the reconciliation process. The research sheds light on reconciliation as a discursive imagination, while still maintaining a general perspective that reconciliation is a method people use in or outside the courts to resolve disputes. The research investigates proliferations of reconciliation discourse as it enters national political space. The analysis of transnational proliferation of discourse relies on the notion of 'critical disjuncture' (Appadurai, 1996) to examine discursive shifts that produce a specific political and legal constellation

1 A complete version of this research summary will appear in a forthcoming issue of the Max Planck Institute for Social Anthropology Working Paper Series. 
to come to terms with the legacy of New Order violence. The research maintains that 'critical disjuncture' emerges when state apparatuses, human rights activists, public intellectuals and victims of violence resort to the transnational discourse of reconciliation to negotiate their engagement with the legacy or the memory of violence. This 'critical disjuncture' constitutes the social life of reconciliation that is the focus of my research. My interest rests less on analysing different forms of reconciliation than on following the processes that make reconciliation what it is, whatever form it takes.

\section{Reconciliation: Its First Life as a Political Reconciliation}

Social scientists studying legal processes have often demonstrated how people resort to reconciliatory practices to resolve disputes over property rights, inheritance or domestic violence. However, only in the 1990s did people resort to reconciliation to resolve state violence or communal conflict, even though violence committed in the name of state ideology has been as old as the concept of the state itself. Reconciliation as a political concept deployed to resolve conflicts between state apparatuses and citizens of the state is a recent practice, enabled by the changing function of the state as an arbiter of social justice. The function of the state often changes after a period of massive violence or during the transition from an authoritarian regime. I demonstrate in this research that the changing function does not always invoke reconciliation as a major political discourse to deal with past violence.

The ending of an authoritarian political regime could drive a politically calculated move to create a commission with a mandate to investigate the alleged violence of the former regime. However, the existence of a commission does not necessarily strengthen human rights values. The most blatant instance is Uganda, where a commission of inquiry on missing people was created in 1974 by President Idi Amin, but at the same time the president committed the most brutal human rights violation the world has ever seen (Hayner, 2002: 51-52).

The period 1982 to 1990 witnessed the establishment of at least six 
commissions of inquiry in Latin America, Africa and Asia. As the names of the commissions indicate, they are created usually to investigate people's disappearance. In so doing, they had limited jurisdictional reach and failed to touch upon the larger context of human rights violation (Hayner, 2002: 305-206), let alone promote a stronger democratic climate in their countries.

In 1990, President Patricio Alywin of Chile introduced an unprecedented policy to establish a commission with dual responsibilities. The Chilean National Commission on Truth and Reconciliation was given a mandate to investigate extrajudicial killings and at the same time to think about a strategy for compensating the victims without going through a difficult trial. This was also the first time a political leader expressed the need for 'forgiveness and reconciliation' in the context of an investigative commission's work.

Chile has pioneered a new direction in the transnational politics of human rights and this discourse of reconciliation appeared five years earlier than the famous South African Truth and Reconciliation Committee (TRC). However, the Chilean reconciliation effort failed to capture public attention. Instead, it was the South African TRC that has served as a model for subsequent reconciliation commissions. Part of the explanation of why the South African TRC was relatively more successful than the Chilean commission was the active and direct involvement of Archbishop Desmond Tutu and the Catholic Church in South Africa in facilitating the reconciliation program. In so doing, the active role played by the South African Catholic Church has strengthened the moral and ethical cause of the reconciliation.

The success story of the South African TRC in creating a working platform for a national reconciliation has inspired many human rights activists and post-authoritarian governments to consider a similar policy in dealing with past violence. Such policies offer another way to resolve the traumas of human rights violations without involving judicial systems that might be still influenced by the legacy of an authoritarian past. The work of the South African TRC highlights a shared concern on national identity and national harmony, presented 
beyond a rational legal discourse or beyond painstaking efforts to uncover suppressed historical facts. The South African reconciliation work privileges the discourse of national ethics over the need for judicial inquiry or historical investigation. By incorporating the ethics of a good and harmonious citizenship into the project of reconciliation, South Africa has shaped the transnational human rights 'ideascape'. The ethical framing transforms the South African reconciliation into a 'transportable' discourse, appropriated further by similar initiatives for reconciliation in other countries.

\section{Indonesia's Encounter with Reconciliation}

Indonesia has been part of the transnational traffic of the human rights idea since long before Reformasi (Reform) started. However, prior to 1998, the security organisations allowed only a limited space for human rights advocacy. When the New Order regime crumbled, the state lost its control of the human rights movement and many activists responded by forging international connections to strengthen their political bargaining position.

Some non-governmental organisations, pioneered by Elsam (Lembaga Studi dan Advokasi Masyarakat [Institute for Policy Research and Advocacy]) and Kontras (Komisi Untuk Orang Hilang dan Korban Tindak Kekerasan [Commission for 'The Disappeared' and Victims of Violence]), began to work with former political detainees from the tragic events 1965-66 and called on the post-New Order regime to resolve two matters. First, the state should initiate a thorough investigation of the extrajudicial killings that took place in 1965-66. Second, the state should end political and social discrimination against former political detainees and rehabilitate their political and citizenship rights. This was the time when the ideas of reconciliation entered the public discourse of human rights in Indonesia, even though since then human rights activists have had different thoughts on how the initiative of reconciliation should proceed. Some acknowledge that reconciliation can help resolve the legacy of the 1965-66 violence, but the activists insist that the 
state must first initiate a thorough investigation and establish an ad hoc human rights court to bring the masterminds of the tragedy to justice. Other activists voice a more modest demand: they believe that the human rights court is a lesser priority than a general public statement by the government that acknowledges the involvement of the New Order security organisations in the massacres. This latter group puts more stress on rehabilitating the political, social and economic rights that the New Order regime denied to the former political detainees.

In 2000, the former political detainees and their families received a nice surprise. President Abdurrachman Wahid offered an apology for the suffering and discrimination the detainees had experienced. Even though the president mentioned nothing about investigation and historical clarification, his statement was a strong symbolic gesture. Because he was the most respected leader of the Nahdlatul Ulama (NU), Wahid's statement could be interpreted as a symbolic offer of reconciliation between the NU and the detainees. It gained more important political value when recent studies of the 1965 tragedy reveal that the youth wing of the NU, the Banser, played an active role in supporting the army's part in the massacres.

President Wahid offered his unprecedented apology at the time when human rights politics in Indonesia entered a new stage. The period 1999-2000 saw the development of new legal processes that affected the politics of reconciliation. The first development was the enactment of the law 39 of 1999 on human rights. Even though Indonesia had already established Komnas HAM (Komisi Nasional Hak Asasi Manusia), the national commission on human rights in 1993, only in 1999 did Indonesia enact a human rights law. The second development was the enactment of law 26 of 2000 to establish the Ad Hoc Human Rights Court. The law opened a new legal procedure that complements the Indonesian penal code by supporting the establishment of a specific court for criminal acts that can be categorised as a 'gross human rights violation'. However, law 26 of 2000 makes no mention of reconciliation, which means that the state legal system recognised the ad hoc human rights court as the only mechanism to resolve human rights violations. 
Elsam drew attention to the juridical limitation of law 26 of 2000. The NGO sought another way to overcome this limitation by preparing a legal draft for an Indonesian Truth and Reconciliation Commission (Komisi Kebenaran dan Rekonsiliasi or KKR) and presented it to the Ministry of Justice and Human Rights. The ministry later submitted the draft to the parliament but it was different from the one prepared earlier by Elsam. After long and complex negotiation, the parliament eventually enacted, in 2004, law 27 of 2004 on the Indonesian Truth and Reconciliation Commission (UU KKR). The law, however, did not remain in force long. In responding to a judicial review, requested by a coalition of human rights NGOs, the Constitutional Court revoked the law in 2007. Since then, the discourse of reconciliation has lost its place in the state legal system.

The idea that Indonesia should have a truth commission has faced a strong resistance from state officials, security organisations and nationalist groups. Of the two major elements of the truth commission, that of truth-seeking (kebenaran) has provoked more reactions than the element of reconciliation (rekonsiliasi). The reactions coalesce in the discourse of malu (shame), which suggests that exposing past violence would bring shame (memalukan) to alleged perpetrators. Each time their self-esteem was violated, the perpetrators would feel uneasy about, or even refuse to discuss, reconciliation with the victims. In this research I suggest that the emotional debate over malu demonstrates how the discourse of reconciliation in Indonesia resorts to social ethics to shape human rights politics.

In studying human rights politics outside the realm of the state legal system, this research follows an assumption, developed in the study of legal pluralism, that legal processes should not be limited only to the state judicial realm. In so doing, the research places less emphasis on the analysis of legal documents and court processes and pays more attention on the ethical and religious dimensions of reconciliation as a cultural practice. Studies on human rights carried out by legal scholars and activists tend to conceptualise human rights as a secular project. However, some Asian human rights activists have criticised the 
separation of religious and secular categories in understanding human rights politics and practices. They argue that many Asian and African societies still rely on religions to animate public life. As a consequence, religion affects human rights norms, politics and practices in one way or another. This research supports that view and draws on the plural constellation of normative frameworks to understand islah reconciliation effort in Tanjung Priok and an attempt to reconcile the former political detainees with the Nahdlatul Ulama community in Central Java. ${ }^{2}$

\section{Tanjung Priok Islah}

In 1984, there were tragic events in Tanjung Priok, North Jakarta. The army's excessive response when trying to disperse Muslim protesters led to a bloody massacre with more than 50 people killed. For fifteen years the New Order regime managed to suppress the facts related to the killings but after 1998 the families of the killed and 'disappeared' people began to organise in order to break the official silence. In so doing, they have received institutional and financial assistances from Elsam and Kontras. The NGOs facilitate a network, organise public rallies, issue public statements and call for the government to re-open the case.

At the same time, some military officers, allegedly involved in the tragedy, launched an initiative to contact and organise a meeting with the victims. On 1 March 2001, a public gathering, called islah, was held at Sunda Kelapa Mosque in Central Jakarta. As well as the Tanjung Priok people and the military officers led by retired General Try Sutrisno, also present at the islah gathering were the Commander of Jakarta Military Command and Dr Nurcholish Madjid, a Muslim intellectual. The military officers suggested islah to serve as a reconciliation forum, drawing on an ethical discourse that emphasises a shared obligation to act as good citizens. A good citizen is someone who is able to overcome resentment and forget the past for the sake of the nation.

2 Islah derives from Arabic, literally means "forgetting the past to achieve peace." 
The islah gathering concluded with a ceremonial signing of Piagam Islah (Islah Charter). The charter is not an ordinary legal document. It invites one to interpret it as a material representation of a moral discourse that shapes the islah. The document includes several Qur'anic verses that talk about God's calling for Muslims to make peace with fellow Muslims. By incorporating the verses into the Islah Charter, the military as the initiator of the islah has delivered a strong moral that God and Islamic norms demand communal harmony. The discourse of reconciliation put forward by the Islah Charter presents the reconciliation not only as an ethical project of good citizenship but also a moral project to sustain a religious norm of Muslim brotherhood (umat).

\section{The 1965-66 Reconciliation}

In 2000, young activists affiliated with the Nahdlatul Ulama set up a non-governmental organisation called Syarikat. This organisation's priority is to bridge a social and communication gap between former Banser militia members and former political detainees. In 2003, Syarikat held 'grass-root reconciliation meetings' in Bondowoso and in Cirebon, attended by local NU kiais from East and West Java, former members of Banser militia groups and by former political detainees.

Syarikat adopted two major strategies in its reconciliation work. First, it organised gatherings such as those held in Bondowoso and Cirebon. Second, it published memoirs written by some former members or sympathisers of the Indonesian Communist Party; people who were also prominent Islamic leaders in the 1960s. This was part of Syarakat's advocacy strategy, that is, to highlight the fact that no 'natural connection' exists between communism and atheism. This is to counter the argument that conservative kiais and the Banser militia always put forward, which is to label the communists as atheists. Syarikat activists see that an ideological barrier separates the NU community and the political detainees and, for reconciliation to succeed, someone must breach the wall. Without taking into account the religious nuance, the reconciliation initiative would face a strong resistance because the kiais 
and the Banser would insist on the belief that the killing in 1965-66 was a religiously sanctioned act.

\section{Conclusion: the Social Life of Reconciliation in Indonesia}

The discourse of reconciliation goes back to no earlier than the 1990s, when the Chilean government sought a proper means to end the cycle of tension between the military and relatives of the 'disappeared'. The Chilean alternative departed from the common procedure used at the Nuremberg Trials to resolve human rights abuses. The Chilean initiative of reconciliation is a crucial development because it draws attention to the moral and the ethical dimension overlooked in the post-war human rights trial.

The moral and the ethical aspects of reconciliation direct the work of the South African Truth and Reconciliation Commission. The South African TRC work has served as a model for later reconciliation projects in Asia, Latin America and Africa. The involvement of Archbishop Desmond Tutu in South Africa, and later Archbishop Bello in East Timorese reconciliation, has strengthened the notion of reconciliation as a moral and ethical project by emphasising that the reconciliation is less a judicial mechanism than a project to revive the images of good citizenship and an enduring social collectivity. In this research, I propose that this particular kind of moral and ethical project renders reconciliation as a transnational 'transportable' ideascape that has also shaped the discourse of reconciliation in Indonesia.

This research highlights critical disjunctures emerging from the encounters of the transnational ethic of forgiveness with the reconciliation norm that draws on the social ethic of good conduct and the religious ethic of Muslim brotherhood. In the Tanjung Priok islah, the military involves a moderate religious figure and incorporates specific Qur'anic verses in the Islah Charter to place the reconciliation initiative in the imagination of good citizenship and of a religious fold. Although the islah forum draws its authority from Qur'anic verses, the Syarikat's attempt to reconcile the political detainees with the NU community depends 
on the authority held by the local NU kiais. Syarikat appropriated the idea of reconciliation to rehabilitate the social and political rights of the detainees and at the same time it addresses an ethical project to bring the former detainees back to the Muslim fold.

This project maintains that in Indonesia reconciliation projects emerge from the critical disjunctures formed when the global ideascape of justice and rights encounters a specific moral and ethical predicament. I would like to emphasise that the analysis of reconciliation should pay more attention to various 'projects' that do not necessarily support the concept of reconciliation as an alternative judicial mechanism. In post-1998 Indonesia, the military and the Syarikat have incorporated religious norms into political reconciliation, situated in a larger discursive imagination to constitute the post-authoritarian fold of ethical citizenry.

\section{References}

Appadurai, Arjun. 1996. Modernity at large: cultural dimensions of globalization. Minneapolis: University of Minnesota Press.

Hayner, Priscilla B. 2002. Unspeakable truth: facing the challenge of truth commissions. New York: Routledge. 